\title{
Past and Future Trends in Medical Spas: A Co-Word Analysis
}

\author{
Alina-Cerasela Aluculesei ${ }^{1,2, *} \mathbb{C}$, Puiu Nistoreanu ${ }^{1} \mathbb{C}^{\mathbb{D}}$, Daniel Avram ${ }^{1}$ and Bogdan Gabriel Nistoreanu ${ }^{3}$ \\ 1 Department of Tourism and Geography, Faculty of Business and Tourism (Formerly Commerce), \\ Bucharest University of Economic Studies, 010404 Bucharest, Romania; puiu.nistoreanu@com.ase.ro (P.N.); \\ avram89@yahoo.com (D.A.) \\ 2 Institute for World Economy, Romanian Academy, 050711 Bucharest, Romania \\ 3 Faculty of Business Administration in Foreign Languages, Bucharest University of Economic Studies, \\ 010404 Bucharest, Romania; bogdan.nistoreanu@fabiz.ase.ro \\ * Correspondence: alina.cerasela@iem.ro
}

Citation: Aluculesei, A.-C.;

Nistoreanu, P.; Avram, D.;

Nistoreanu, B.G. Past and Future

Trends in Medical Spas: A Co-Word Analysis. Sustainability 2021, 13, 9646. https://doi.org/10.3390/su13179646

Academic Editors: Pantea Foroudi,

Maria Palazzo and

Dan-Cristian Dabija

Received: 6 July 2021

Accepted: 12 August 2021

Published: 27 August 2021

Publisher's Note: MDPI stays neutral with regard to jurisdictional claims in published maps and institutional affiliations.

\begin{abstract}
The present paper consists of a co-word analysis of the previous research in the medical spa field published in the Web Science Core Collection database. The study's main purpose is to identify the past trends in the medical spa field from the tourist and medical perspectives and to anticipate the future research focuses in the field. In this regard, the article is based on four objectives that create a descriptive picture of the research in the medical spa area, such as (i) studying the current state of the art, (ii) analysing the most visible articles in the field, (iii) highlighting the leading research interests in medical spa research and (iv) anticipating new possible research trends that link cost-effective medical spa activity to COVID-19 post-recovery treatments. A total of 627 articles, published between 1997 and 2021 (March), were analysed, and the data were interpreted using the VOS Viewer software. The study results indicate that high interest in medical spas started to become observable in 2015, when the funding bodies became interested in this field and began supporting publishing and research regarding medical spas. The main subjects investigated in previous studies were related to the specific issues of the industry and tourism activity. They also considered the medical approach of the spa and the use of natural resources in treating different diseases. Except for these main interests, since 2020, it has started to become evident that another approach in the published studies may lead to a new trend in research. The study results show that researchers have begun to investigate the possibility of using medical spa resorts to aid post-COVID-19 recovery, which is considered a cost-efficient option for completing traditional treatment. This new focus in research proves that the medical spa field can rebrand itself as playing a supportive role in national healthcare systems in countries with a long tradition in balneotherapy, and gives a new developing trajectory to the medical spa industry.
\end{abstract}

Keywords: medical spa; spa; spa therapy; balneotherapy; COVID-19 recovery; cost-effective COVID19 therapy; co-word analyses

\section{Introduction}

Tourism represents one of the main economic pillars in the European Union, creating new jobs and helping local communities to diversify their activities [1]. The COVID-19 pandemic has affected the industry dramatically, and the numerous lockdowns declined international tourist arrivals by $65 \%$ in the first half of 2020 compared to the same period in the previous year [2]. In the past decades, tourism recorded constant growth, and many countries, like Greece [3], Italy [4], Spain [5] and France [6] focused on their tourist potential to boost their economies. The changes in tourist demand due to the COVID-19 pandemic overlapped with the emergence of a new tourist profile characterised by a more informed and exigent traveller [7], which has forced the industry to rethink their market strategy [8]. As a consequence of the COVID-19 pandemic, tourists have started to rank destinations according to their level of safety in terms of epidemiological risk [9]. In this context, the 
loyalty of tourists to famous spots disappeared [10], as the travel fear of tourists became a constant. In the following years, this travel fear is expected to last and to remain one of the main issues of the tourism industry after the pandemic is over [11], continuing to affect the decision-making process [12].

The dramatic decrease in international travel in 2020 raises the question of how the industry will look after the COVID-19 pandemic, and in particular how the profile of tourists will continue to change in the following years. This question is of interest to stakeholders, since travel has been banned or restricted since March 2020. Even though many destinations have assured potential visitors that all necessary safety measures had been taken, international travel remains a challenge. In the context of the long tradition of medical spas in treating respiratory diseases [13], there is also the question of whether tourism in general, and health tourism in particular, can contribute to overcoming this health crisis. In the context of the global growth of COVID-19 cases and taking into account the particularities of the COVID-19 infection, which affects mainly the respiratory system, spa tourism, through its medical spa component, could be a potential cost-effective solution for the healthcare systems of countries that have a long tradition of health resort activity. This suggestion has started to be emphasised in the academic environment [14], and there are already resorts that offer dedicated programs for COVID-19 recovery [15].

Moreover, the health crisis has put considerable pressure on the world's medical and economic systems and has forced stakeholders to look for cost-efficient solutions. In this regard, spa tourism could also represent an option to support healthcare systems in post-COVID-19 recovery therapies, since spa therapy is considered cost-efficient [16]. The actual health crisis and the spread of medical spas around the globe has created room for this type of tourism to build on this momentum by assisting healthcare systems with the recovery processes of COVID-19 patients.

Considering that medical spas could have a central role in the pandemic recovery, in this study we investigated the past trends in medical spa research using co-word analysis. The general objective of the paper was to illustrate a descriptive picture of the research in the medical spa field and to anticipate future research trends, like the link between medical spa activity and COVID-19 post-recovery therapies. In this regard, we accomplished a bibliometric analysis of the articles published in WOS Core (Web of Science Core Collection) in the spa field between 1997 and 2021 (March). Additionally, we highlighted the leading journals and authors that contribute to this field, assuming that the top research teams will continue to influence research in the spa field in the following years too. Our study also investigated the level of commitment of funding bodies to supporting research in the spa field, assuming that funding organisations' attraction to a research area indicates the importance of the subject being invested in.

Taking into account the particularities of medical spas in Europe, which are generally recognised for their healing properties, and the challenges of the COVID-19 crisis, the present study's findings represent a starting point for researchers to better understand the current state of spa tourism from a medical perspective. The results also offer a comprehensive overview of the possibility of spas with experience in treating respiratory diseases to participate in COVID-19 recovery programs.

The study employs a new approach to analysing the published research in the medical spa discipline, using both tourist and medical perspectives. In this regard, the results highlight past trends in research and anticipate future research focuses.

\section{Health Tourism-Definition and Implications}

Health tourism represents an umbrella concept that includes medical tourism, wellness tourism and spa tourism [17]. The most important health tourism destinations in the EU based on revenue are France, Germany, Italy, Sweden and Poland. In contrast, the highest geographical densities of health and wellness facilities are found in Central and Eastern Europe, Spain and the southern Baltic coast [18]. 
A high dynamic was recorded within the last decades in all three components of health tourism, and as a consequence, many new niches developed. For instance, we can meet subcategories like rural well-being tourism [19] or dental tourism [20], which illustrate the complexity of health tourism and the interest of tourists in new ways of improving their health status. Because the three components of health tourism have developed continuously, and innovative new products have appeared on the market, confusion between terms also developed. Moreover, because of the differences in the traditions involving the usage of natural curative resources for healing purposes from one country/region to another, the confusion is more obvious in the case of spa tourism. Some countries recognise the importance of medical spas, while others question their impact on the human body. The main differences between the two belief systems are related to the primary purpose of tourism activities and natural resources. For example, wellness tourism promotes personal well-being and allows people to maintain or enhance their health [21]. Spa tourism "focuses on healing, relaxation or beautifying the body, being considered preventative and/or curative" [18]. Medical tourism represents a solution for the patients who cannot access specific healthcare services in their country/region of origin, due to the lack of availability or high costs [22,23]. International travel became more accessible in the last two decades. Internet development allowed providers to offer detailed information through their websites and dedicated platforms. Internet has also become an essential tool in market segmentation and helps providers in reaching specific tourist profiles [24] while also offering personalised services, depending on needs and desires [25]. Social media platforms are also important in attracting tourists and disseminating information [26]. Moreover, the availability of valid information about tourist services is an actual requirement of tourists [27]. In this context, medical tourism became one of the most promising types of tourism. Many countries started to focus their tourist marketing campaigns on medical tourism in order to attract foreign patients [28]. However, it is hard to understand all the parts of the medical tourism, due to the lack of data regarding the healthcare provided to foreigners in each country/region and because the methodology in recording foreign patients varies from one destination to another. Defining the medical tourism term represents another challenge as there is no agreedupon definition [29]. Moreover, there are many issues related to medical tourism. First, it represents an unregulated market [30], which leads to controversies, as transplant tourism is considered a growing problem [31]. Secondly, the data regarding follow-up and clinical outcomes is unknown [22]. Ethical issues also arise in relation to medical tourism, like providing healthcare services to foreigners in countries where not all the citizens have access to similar services [32]. Another ethical aspect is the accessibility of foreigners to treatment that in their country of origin is not legal, which highlights the need for an international legal framework in medical tourism [33]. Specialists also describe the risk for patients to return with infections after a health procedure in another country and point out the importance of being informed about the clinic they choose and the medical procedure they will submit to in a foreign country [34].

Despite the diverse issues related to medical tourism, people continue to travel for healthcare purposes. Hungary is one of the leading destinations for medical tourism in Europe, with around 500,000 tourists each year [35]. It became famous mainly for its dental tourism that started to be a reference point in the industry since the beginning of the 1990s [36], attracting patients from neighbouring countries and overseas [37]. Besides Hungary, Czech Republic is also visible on the international market for having renowned cheap dental treatments. Other European countries with potential in medical tourism are Slovenia [38] and Bulgaria [39]. The most attractive destinations formulated their strategy based on modern methods of information search which facilitate the interaction between foreign patients and medical providers. Even if it was proven that online information exerts limited influence on the decision-making process of the patients, internet tools became mandatory in the effort of the providers to get closer to the patients $[40,41]$. 
Wellness tourism is preferred by the tourists who want to maintain or improve their health and well-being status [42]. In this regard, the main purpose of the tourists who prefer wellness tourist destinations is to enhance their health when travelling [43]. Due to the ageing population and people's desire to have an active and healthy life, the interest in wellness tourism has increased during the last years [44,45]. The growth of demand in wellness services is obvious in countries that have a larger percentage of ageing population like China [46], and it is estimated that North America, Western and North Europe will also need these services in a short period of time [47].

Along with medical and wellness tourism, spa tourism recorded an interesting growth among tourists and became notorious even among youth. Spas, historically, have been developed in areas rich in natural healing sources [48] and have usually been seen as symbols of local identity [49], although their golden age belongs to the past 18th and 19th centuries [50,51]. Over time, spas have seen different phases of evolution, and nowadays, their offer is more complex and includes even aromatherapies, yoga, Pilates and other similar programs [52].

Every year thousands of people travel to Europe to improve their welfare and wellbeing [53]. Different terminologies have been developed depending on the historical background of each region, and these include balneology, thermalism or medical hydrology. These concepts are more linked to the medical side of the traditional spas where balneology, for example, uses [54] climate factors as part of a complex therapy [55]. Balneotherapy is generally found in Central and Eastern European countries, where the usage of thermal and mineral waters for healing is part of the cultural heritage and the medical tradition [56] and have been frequently used even as a complementary therapy [57] for various skin conditions [58]. Romania is known for having the highest potential in balneology and spa tourism in Europe, with around 30\% of the European natural therapeutic resources located in different regions of the country [59] that consist of "climate; mineral and thermal waters; mud and gases" [60].

Although bathing in healing waters has been used since antiquity in many regions to cure different diseases $[61,62]$, the procedure still has its critics. The most relevant criticism is the lack of scientific evidence in health improvement. As a consequence, balneology started to be redesigned with more of a wellness approach in mind [63]. Moreover, there are differences in approaching healing cures that involve natural factors worldwide, mainly between the United States and Europe. On the one hand, in European countries the healing effects of natural factors are recognised. They have traditionally been oriented towards providing medical care or treatment for different illnesses [64]. In the European countries, important stakeholders, like the European Commission and the World Health Organisation, also organise recurrent meetings and conferences that emphasise the medical approach of these therapies [65].

On the other hand, North American spas have a wellness-focused approach and have left their medical influence behind [66]. We can find practice differences in other destinations also. In Asia, spa services mainly focus on traditional and spiritual approaches, including massages, acupuncture and hot spring therapies [67]. As time passed, the changes in the tourists' demand transformed medical spas. The modern spa is not strictly connected to natural sources anymore. Nowadays, it appeals to a broader audience than the traditional spas [68], making medical spas known through all age groups. In addition to Central and Eastern Europe, medical spa resorts can also be found in "German-speaking countries, France, the Baltic States and Russia" [69].

Despite the criticism, there are plenty of studies that prove spas' impact on health and highlight the positive effects in treating different diseases, like osteoarthritis [70], rheumatism [71] and cardiovascular disease [72]. The beneficial effects of thermal waters on health have been empirically recognised for centuries in terms of symptom alleviation and treatment of several diseases, with most of them associated with inflammation [73], but also including respiratory diseases. Moreover, it was proven that thermal water therapies might improve human immune function [74]. 
In this context and considering that traditional spas have the necessary infrastructure [75] both in terms of human resources and technical aspects, medical spas could support the survivors of COVID-19 that need recovery treatment to improve their health status [76]. Moreover, balneotherapy treatments are more cost-efficient than traditional therapies [16] which consists an advantage in the context of increasing health expenditures worldwide. Another advantage of using medical spas in treating post-COVID symptoms is the overall positive image of the citizens regarding spas that have already shown interest in this type of recovery treatment [77]. Therefore, spa therapies could be easily accepted and trusted by the COVID-19 patients needing recovery after traditional treatment received in the hospital.

\section{Materials and Methods}

Considering the importance of research studies for evidence-based practice, we investigated what the focus of research in the spa field has been until now and if new research trends could develop in the near future. The present article consists of a bibliometric analysis of the articles published in WOS database between 1997 and March 2021 using the co-word analysis.

The co-word study investigates the co-occurrences of key words and identifies the relationships and interactions between the researched topics. It also emphasises research trends [78] and the most influential authors in the tourism field [79]. Bibliometric research illustrates a systematic overview of the evolution of research $[80,81]$ based on published papers from the academic environment $[82,83]$ and is a valuable tool for stating future research in a field [84]. The analysis creates a suggestive map of the strength of association between keywords in textual data [85] that is used in a wide range of studies in tourism [86,87] and other fields [88]. A co-word analysis considers the dynamics of a field and identifies the changes in a subject area [89]. It represents a rigorous method of investigating big amounts of data and has started to be used in the business field also [90]. This type of research method helps scientists investigate research trends using specific software since data availability increased dramatically in the last years and, as a result, traditional techniques have trouble helping us understand the research approaches [91].

Based on the advantages of this type of research that offers the opportunity to reproduce studies of the literature [92], we established our paper by studying articles and proceedings in the spa field that approached the spa activity from the tourist or medical/health perspective. The study's primary purpose was to find out what has been the research focus over the years in the spa field and to identify the opportunities in research in the following years, taking into account the actual health crisis and the potential importance of medical spas in post-COVID-19 recovery.

We also aimed to obtain a detailed overview of the published studies in the spa field that have a touristic or a medical/health approach, and could be a valuable input for future research in this area. We chose to include tourism studies that approached the medical spa field because, as we showed in the literature review part of the article, historically, spas have both medical and touristic components.

From the study of the literature, we found out that other bibliometric studies focused more on investigating the medical tourism segment from the medical point of view [92-94]. They based the research on analysing keywords like "medical tourism", "healthcare", "health tourism" or "wellness tourism". There are also studies that focused on niches of spa tourism like thermalism or thalassotherapy [95]. Some studies investigated the policy research on medical tourism [96] and the contribution of natural resources to health tourism [97]. As the published bibliometric analysis focused on the health tourism field, approaching mainly the impact of the cures of the human health and the study of natural resources, we identified a gap in approaching medical spas from the touristic perspective. The novelty of our study consists of analysing the research in medical spa tourism including both medical and touristic perspectives and completing the classical picture of the bibliometric results with useful details for the stakeholders like the origin of the main 
research teams and the most preferred journals, as well as the funding bodies interested in supporting research in the field. Through the present study, we aim to describe, using the co-word analysis, the focus in previous research in the spa industry from the point of view of the tourism and medical/health approach and to investigate if there are already links in research between spa therapies and post-COVID-19 recovery. To approach the primary purpose of the study, we considered four main objectives (Table 1):

Table 1. The structure of the study's objectives.

\begin{tabular}{|c|c|c|c|}
\hline & The Objective of the Study & Output & Resource Used \\
\hline (i) & $\begin{array}{l}\text { Describing the current research state of the } \\
\text { articles from the spa research field. }\end{array}$ & $\begin{array}{l}\text { Output: obtaining an overview of the main } \\
\text { journals considering the publishing } \\
\text { country/region, the number of the articles, } \\
\text { the total number of citations and their rank } \\
\text { after the impact factor (the quartile } \\
\text { category). }\end{array}$ & $\begin{array}{c}\text { Excel software based on WOS } \\
\text { extraction; }\end{array}$ \\
\hline (ii) & $\begin{array}{l}\text { Identifying the main articles in terms of } \\
\text { visibility and citations in the spa field and } \\
\text { the funding bodies' interest in this field. }\end{array}$ & $\begin{array}{l}\text { Output: the analyses of the most visible } \\
\text { and influential articles in terms of citations } \\
\text { in the WOS database. We also included } \\
\text { here aspects as funding bodies, visibility on } \\
\text { the Research Gate Platform, and the } \\
\text { articles' dynamic over the years. }\end{array}$ & $\begin{array}{c}\text { Excel software based on WOS } \\
\text { extraction; }\end{array}$ \\
\hline (iii) & $\begin{array}{l}\text { Identifying the main research interest and } \\
\text { the main clusters of terms used both in the } \\
\text { title and in the abstract of the articles. }\end{array}$ & $\begin{array}{l}\text { Output: clusters of items used in the } \\
\text { metadata of the article (title and abstract). }\end{array}$ & WOSViewer; \\
\hline (iv) & $\begin{array}{l}\text { Investigating whether there is a visible } \\
\text { interest in connecting spa tourism with } \\
\text { COVID-19 in the published papers. }\end{array}$ & $\begin{array}{l}\text { Output: terms network related to } \\
\text { COVID-19. }\end{array}$ & WOSViewer. \\
\hline
\end{tabular}

The four objectives were approached using VOS Viewer features that allowed us to build the main clusters of keywords used in the article's metadata and estimate the future research focus on the field. The research was doubled by the processed data in Excel that allowed us to investigate in detail the typology of the main important journals in terms of published articles.

We selected research articles and proceedings published in English, as VOS Viewer is limited only to the English language [98] and included papers in the WOS database between 1997 and 2021 (31 March). We chose this database for our research because it is considered the primary citation database and the first database that allowed the bibliometric study due to its features [99]. In our study, we considered all the indexes: SCI-EXPANDES, SSCI, A\&HCI, CPCI-S, CPCI-SSH, BKCI-S, BKCI-SSH, ESCI, CCR-EXPANDED, IC. and based our research on four phases of selection and data cleaning (Table 2).

Phase I of the selection data process refers to the first selection step that included the primary selection criteria based on such filters as the timespan, the keywords searched, the language of the papers (English) and the types of the documents (journal articles and proceedings). We considered in our research papers that contained keywords associated with the spa industry in the title, like: "spa", "spa tourism", "spa resort", "spa hotel", "spa town", "spa resources", "spa therapy", "spa facilities", "medical spa", "balneotherapy", "balneology", "thermalism", "thermal water", "hot spring", "hot spring therapy", "sanatorium", "climatotherapy", "mineral and thermal water", "water cures". In this stage, 10,188 items were selected.

The second phase referred to the selection of the papers from the area of interest of our study, filtering the results after the following topics: tourism/health/medical. The total number of the generated articles was, in this phase, 627, which represents our research base for the present study. 
Table 2. The research design of the study.

\begin{tabular}{|c|c|}
\hline Selection Data Phase & Output \\
\hline $\begin{array}{l}\text { Phase I } \\
\text { Location: WOS database, in All Indexes } \\
\text { Search type: Multiple searches after specific keywords in the } \\
\text { document's title } \\
\text { Timespan: all (1997-31 March 2021) } \\
\text { Language: English } \\
\text { Document type: articles and proceedings }\end{array}$ & Total of papers resulted: 10188 . \\
\hline $\begin{array}{l}\text { Phase II } \\
\text { New search filter included: the topic of the paper (tourism OR } \\
\text { health OR medical) }\end{array}$ & Total of papers resulted: 627 . \\
\hline $\begin{array}{l}\text { Phase III } \\
\text { Export step: The export selection was configured for WOS } \\
\text { Viewer software (Windows version) and Excel format. }\end{array}$ & $\begin{array}{l}\text { The } 627 \text { items resulted were split into two parts, according to } \\
\text { the WOS Viewer specifications: one part that contains the } \\
\text { records from } 1 \text { to } 499 \text { and one part containing the records from } \\
500 \text { to } 627 \text {. } \\
\text { The export selection included full record option. }\end{array}$ \\
\hline
\end{tabular}

\section{Phase IV}

Additional data for research: the development of the Thesaurus file for the study used to exclude and merge a part of the terms that are too general (e.g., tourism) or similar (e.g., SUA and The

Thesaurus file designed for the study.

United States of America)

The third phase consisted of the data export step. For this point of the study, we used the export function of the WOS database integrated with the VOS viewer software that we used to interpret the results. VOS Viewer software is an open-source tool used in co-word analysis to investigate the links between research teams and the most visible journals considering the number of published articles and the most used keywords in research. It was developed by Leiden University (Leiden, The Netherlands) and is being used in various fields in order to show the focus of research until a specific moment and the opportunities for future studies [100].

The fourth phase of the research consisted of the cleaning data step using the thesaurus file we developed to avoid too general terms that could influence our analysis [101]. We used the model of thesaurus file generated by the VOS Viewer development team and adapted it to our study profile. We followed two main steps in order to clean the data: (a) identify and merge singular and plural forms of the keywords and (b) identify and mark as "terms to be ignored" the keywords that were too general.

\section{Results}

\subsection{The Current Research State of the Papers That Analysed the Spa Industry (I)}

There were 627 papers (articles and proceedings) that met our selection criteria and focused on the spa industry from the tourism and health/medical perspective. The papers included in the present study were published between 1997 and 2021, being divided into 56 proceedings and 571 journal articles. The first 10 journals with articles published related to the spa activity included 89 articles (around $14 \%$ of the total of the articles included in the research). The analysis revealed that two journals were included in the ESCI database (Emerging Sources Citation Index) that did not have an impact factor yet, six were ranked in Q1 and Q2 (single or in combination with Q3) and four journals were included in Q3, considering the impact factor in various domains (Table 3). The 10 journals originated from the USA (4 journals, with 52 articles in total that met our selection criteria), Switzerland (1 journal with 10 articles), Poland (1 journal with 10 articles), Romania (1 journal with 10 articles), Germany (1 journal with 7 articles) and The Netherlands (1 journal, with 7 articles in total). 
Table 3. Top 10 journals with the number of articles published that met the present criteria selection.

\begin{tabular}{|c|c|c|c|c|c|}
\hline & $\begin{array}{c}\text { Publisher } \\
\text { Country/Region }\end{array}$ & Journal & No. of Articles & $\begin{array}{c}\text { Year of Publication/No. } \\
\text { of Articles }\end{array}$ & $\begin{array}{c}\mathrm{Q} \\
\text { (Impact Factor) }\end{array}$ \\
\hline 1 & USA & $\begin{array}{l}\text { International Journal of } \\
\text { Biometeorology }\end{array}$ & 24 & $\begin{array}{c}2021 / 3 ; 2020 / 5 ; 2019 / 2 \\
2018 / 6 ; 2017 / 4 ; 2016 / 2 \\
2012 / 1 ; 2008 / 1\end{array}$ & Q2 \\
\hline 2 & Poland & Acta Balneologica & 10 & $\begin{array}{c}2019 / 1 ; 2018 / 1 ; 2017 / 4 \\
2015 / 4\end{array}$ & $-(\mathrm{ESCI})$ \\
\hline 3 & Romania & Balneo Research Journal & 10 & $2020 / 4 ; 2019 / 3 ; 2015 / 3$ & $-(\mathrm{ESCI})$ \\
\hline 4 & Switzerland & Sustainability & 10 & $2021 / 2 ; 2020 / 5 ; 2019 / 3$ & Q2, Q3 \\
\hline 5 & USA & $\begin{array}{l}\text { Asia Pacific Journal of } \\
\text { Tourism Research }\end{array}$ & 7 & $\begin{array}{c}2017 / 1 ; 2016 / 3 ; 2015 / 1 \\
2013 / 1 ; 2009 / 1\end{array}$ & Q3 \\
\hline 6 & USA & Dermatologic Clinics & 7 & $2008 / 7$ & Q1 \\
\hline 7 & USA & $\begin{array}{l}\text { Environmental Earth } \\
\text { Sciences }\end{array}$ & 7 & $2020 / 1 ; 2019 / 3 ; 2015 / 3$ & Q2, Q3 \\
\hline 8 & USA & $\begin{array}{l}\text { Journal of Clinical } \\
\text { Microbiology }\end{array}$ & 7 & $\begin{array}{l}2020 / 1 ; 2015 / 1 ; 2013 / 1 \\
2011 / 1 ; 2010 / 2 ; 2005 / 1\end{array}$ & Q1 \\
\hline 9 & Germany & $\begin{array}{l}\text { Rheumatology } \\
\text { International }\end{array}$ & 7 & $\begin{array}{c}2018 / 1 ; 2012 / 2 ; 2010 / 1 \\
2006 / 1 ; 2005 / 2\end{array}$ & Q3 \\
\hline 10 & The Netherlands & $\begin{array}{l}\text { Science of The Total } \\
\text { Environment }\end{array}$ & 7 & $\begin{array}{l}2020 / 2 ; 2019 / 1 ; 2016 / 2 ; \\
2012 / 1 ; 2010 / 1 ; 2005 / 1\end{array}$ & Q1 \\
\hline
\end{tabular}

The most visible journal in terms of the number of published articles was the International Journal of Biometeorology published by Springer, a notorious American publishing house. Articles related to the spa industry were published in the journal starting in 2008 ( 1 article). We observed an increased interest from the authors for publishing their research in the spa field in this journal starting in 2017. In the second, third and fourth places were Acta Balneologica, published in Poland, Balneo Research Journal, published in Romania and Sustainability published in Switzerland, with ten articles each. Of all the ten journals, only two publications had the title directly linked to the spa field: the Polish journal (Acta Balneologica) and the Romanian one (Balneo Research Journal). The others suggested other areas related to a higher degree of medical topic, environmental studies or tourism.

The analyse of the most ten visible journals in terms of published articles in the spa field revealed that from the total of 89 articles in these publications, 23 papers (a quarter) were published in 2020 and 2021, after the COVID-19 disease started to spread and became an international health issue. In total, 21 articles were published in 2018 and 2019. The recent focus of the authors in researching the spa industry reached a peak between 2020 and 2021 (until 31 March 2021).

\subsection{The Analysis of the Most Visible Articles in the Spa Field (II)}

A total of 627 articles included in the research had 6756 citations with noticeable differences from one article to another in terms of visibility in WOS Core. There were 170 papers with no citation in the WOS database and 70 papers with one citation. The first ten papers in terms of the citation number in WOS Core counted 1380 citations, representing around $20 \%$ of the total citations. This indicates that a few researchers influence knowledge production and impact the research in the field.

The most visible and influential 10 articles in the spa field had between 89 and 205 citations in WOS database and were published in journals from various research fields, from the social science field to rheumatology, microbiology or geology. The selected articles by the most notorious research teams in the spa field were from the UK (seven journals) and the USA (three journals), with a time range of publication between 2000 and 2015. The research teams were diverse, both in number and the country/region of origin. Except 
for the most visible article that had 206 citations in WOS Core, which was developed by one author, and the article in the seventh rank that recorded 104 citations and was written by three authors (both articles were from the social science field), the others were developed by large research teams composed of five authors (three articles), six authors (one article), seven authors (two articles) and nine authors (two articles). The affiliation of the correspondence authors also varied from one article to another. Except two articles that had the research teams concentrated in Australia, the others were diverse in origin: one from Asia (Taiwan), six from the EU (Italy, Hungary, Poland, France, Germany and The Netherlands) and one from the UK (Table 4).

The 10 most- cited articles in WOS were also highly appreciated on the Research Gate platform, one of the most popular academic platforms worldwide [102], in terms of research interest. The most cited article was "Watering our cities: The capacity for Water Sensitive Urban Design to support urban cooling and improve human thermal comfort in the Australian context" published in 2013. The article had 4020 reads, 263 citations and a research interest score of 190.6 on the Research Gate platform. The following article was published in 2005 and was entitled "Hydrotherapy, balneotherapy, and spa treatment in pain management". It recorded 3342 reads and 261 citations and had a research score of 153.9 on the Research Gate platform.

Table 4. The most visible 10 articles in the spa field in terms of citation according to the research criteria.

\begin{tabular}{|c|c|c|c|c|c|c|c|c|c|}
\hline & $\begin{array}{l}\text { Main Author } \\
\text { Affiliation }\end{array}$ & No. of Authors & $\begin{array}{l}\text { Times Cited in } \\
\text { WoS Core }\end{array}$ & $\begin{array}{c}\text { Pub. } \\
\text { Country/Region }\end{array}$ & Journal Title & Pub. Year & Research Areas & $\begin{array}{c}\text { Research Gate } \\
\text { Visibility (R/C/RI *) } \\
\text { Reads/Citations/ } \\
\text { Research Interest }\end{array}$ & Ref \\
\hline 1 & Taiwan & 1 & 206 & UK & Tourism Management & 2007 & $\begin{array}{l}\text { Environmental Sciences } \\
\text { and Ecology; Social } \\
\text { Sciences-Other Topics; } \\
\text { Business and Economics }\end{array}$ & $\begin{aligned} \mathrm{R} & =282 \\
\mathrm{C} & =313 \\
\mathrm{RI} & =158.6\end{aligned}$ & [103] \\
\hline 2 & Italy & 7 & 188 & UK & $\begin{array}{l}\text { Polymer Degradation } \\
\text { and Stability }\end{array}$ & 2015 & Polymer Science & $\begin{aligned} \mathrm{R} & =392 \\
\mathrm{C} & =175 \\
\mathrm{RI} & =92.4\end{aligned}$ & [104] \\
\hline 3 & Hungary & 6 & 178 & USA & $\begin{array}{l}\text { Rheumatology } \\
\text { International }\end{array}$ & 2005 & Rheumatology & $\begin{aligned} R & =3342 \\
C & =261 \\
R I & =153.9\end{aligned}$ & [105] \\
\hline 4 & Australia & 5 & 170 & UK & $\begin{array}{l}\text { Progress in Physical } \\
\text { Geography-Earth and } \\
\text { Environment }\end{array}$ & 2013 & $\begin{array}{l}\text { Physical Geography; } \\
\text { Geology }\end{array}$ & $\begin{aligned} \mathrm{R} & =4020 \\
\mathrm{C} & =263 \\
\mathrm{RI} & =190.6\end{aligned}$ & [106] \\
\hline 5 & Poland & 9 & 128 & USA & $\begin{array}{l}\text { Journal of Clinical } \\
\text { Microbiology }\end{array}$ & 2005 & Microbiology & $\begin{aligned} \mathrm{R} & =182 \\
\mathrm{C} & =163 \\
\mathrm{RI} & =82.6\end{aligned}$ & [107] \\
\hline 6 & France & 9 & 120 & UK & $\begin{array}{c}\text { Annals of The } \\
\text { Rheumatic Diseases }\end{array}$ & 2010 & Rheumatology & $\begin{aligned} \mathrm{R} & =199 \\
\mathrm{C} & =171 \\
\mathrm{RI} & =87.6\end{aligned}$ & [108] \\
\hline 7 & UK & 3 & 104 & UK & $\begin{array}{l}\text { International Journal of } \\
\text { Tourism Research }\end{array}$ & 2009 & $\begin{array}{l}\text { Social Sciences-Other } \\
\text { Topics }\end{array}$ & $\begin{aligned} \mathrm{R} & =3104 \\
\mathrm{C} & =168 \\
\mathrm{RI} & =99.9\end{aligned}$ & [109] \\
\hline 8 & Germany & 5 & 99 & UK & Rheumatology & 2000 & Rheumatology & $\begin{aligned} \mathrm{R} & =72 \\
\mathrm{C} & =135 \\
\mathrm{RI} & =68.5\end{aligned}$ & [110] \\
\hline 9 & Australia & 5 & 98 & UK & Water Research & 2006 & $\begin{array}{c}\text { Engineering; } \\
\text { Environmental Sciences } \\
\text { and Ecology; Water } \\
\text { Resources }\end{array}$ & $\begin{aligned} \mathrm{R} & =587 \\
\mathrm{C} & =132 \\
\mathrm{RI} & =68.5\end{aligned}$ & [111] \\
\hline 10 & $\begin{array}{l}\text { The } \\
\text { Netherlands }\end{array}$ & 7 & 89 & USA & $\begin{array}{l}\text { Arthritis and } \\
\text { Rheumatism-Arthritis } \\
\text { Care and Research }\end{array}$ & 2002 & Rheumatology & $\begin{aligned} \mathrm{R} & =120 \\
\mathrm{C} & =153 \\
\mathrm{RI} & =76.9\end{aligned}$ & [112] \\
\hline
\end{tabular}

${ }^{*} \mathrm{R}=$ Reads; $\mathrm{C}=$ Citations; $\mathrm{RI}=$ Research Interest.

Regarding the interest of funding bodies to support research in the spa field, we observed differences during the years. Out of the 627 articles and proceedings studied, 245 (almost $40 \%$ of the total) received funding for research. The most interested funding agencies were from the USA ( 25 articles funded) and China ( 25 articles), followed by France (14), Poland (13), Iran (13), Japan (12), Taiwan (12) and Italy (11). By contrast, the CEE countries with the highest concentration of natural resources used in the spa industry attracted less funding. For example, Romania, which holds one-third of the natural spa resources in Europe, recorded four funded articles, like the Check Republic. Serbia recorded five articles that received funding for research in the analysed period (2007-March 2021).

The interest of the funding bodies to finance research in the spa field and the interest of the authors to ask for funding for their research in this area is visible beginning in 2015. 
Between 2006-2014 (before 2006 there were no funded papers in the selected articles and proceedings), the total number of funded papers was 50. Starting with 2015, there were 195 articles that received funds, with a peak in 2019 when 45 papers that received funding were published. In 2021 until 31 March, 13 published papers received funding (Figure 1).

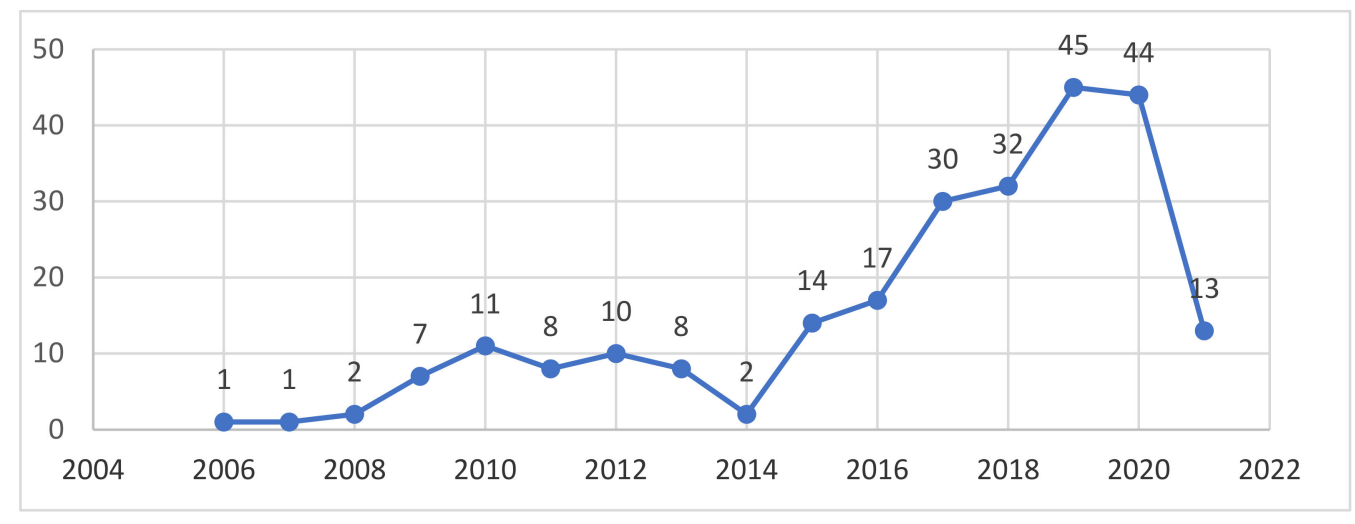

Figure 1. The evolution of funded articles in the analysed time span. For 2021, only the papers that met the selection criteria and were published in the first quarter of the year were analysed.

\subsection{The Main Research Interest of the Authors in the Spa Field (III)}

In order to analyse the research interest in the published papers, we investigated the title and the abstracts of the papers included in our research using VOS Viewer software. We created a map based on the text data using the terms extracted from the metadata of the papers included in the study, choosing the full counting method. We selected the terms with a minimum occurrence of 10; this generated 372 terms that met these criteria out of 15,735 terms. To make sure we had an accurate database, we developed the thesaurus file to exclude the terms without a direct connection to our study, such as: "existence", "answer", "kind", etc. and to combine synonyms, like: "client" / "customer", "guest" /"customer", etc. In total, we included 198 items in our thesaurus file. The analysis findings reveal that "patient (652), "balneotherapy" (244), "quality" (209), "hot spring" (208), and "pain" (182) were the most common terms used by researchers in the metadata of the article (title and abstract).

Five main clusters of terms that suggested the authors' interest in research in the spa field during the 1997 and 2021 (March) period were generated. After we excluded from each cluster the terms that could not be assigned to a category, the structure of the clusters was the following: Cluster I (61 items) covers tourism issues, Cluster II (56 items) contains items related to the medical approach of spas, Cluster III (54 items) includes aspects regarding the natural resources, Cluster IV (31 items) includes issues related to the healthcare and Cluster V ( 3 items) contains items related to COVID-19 (Figure 2).

The authors who focused their research on the tourism side of the spa industry (cluster I) used terminology like: "service" (occurrence: 108), "resource" (95), "experience" (90), "tourist" (82) and "satisfaction" (78). The items from this cluster can be split into four main categories (Table A1 in Appendix A), such as: destination - the three most used items were: destination (occurrence: 40), Poland (33), Romania (27); tourist experience-experience (90), culture (34), relaxation (27); future issues related to the spa industry-technology (30), growth (24), innovation (24), and tourism industry aspects-service (108), resource (95), tourists (82).

The group of articles that focused on the medical approach of spas had as main keywords: hot spring (208), area (169), sample (137), temperature (102) and region (95). The items from this cluster can be divided into four categories: destination - area (169), region (95), city (54); medical aspects-measurement (52), performance (49), investigation (48); risks associated with the field - radon (55), metal (22), health risks (19); and spa-related issues-hot spring (208), temperature (102) and source (81). 


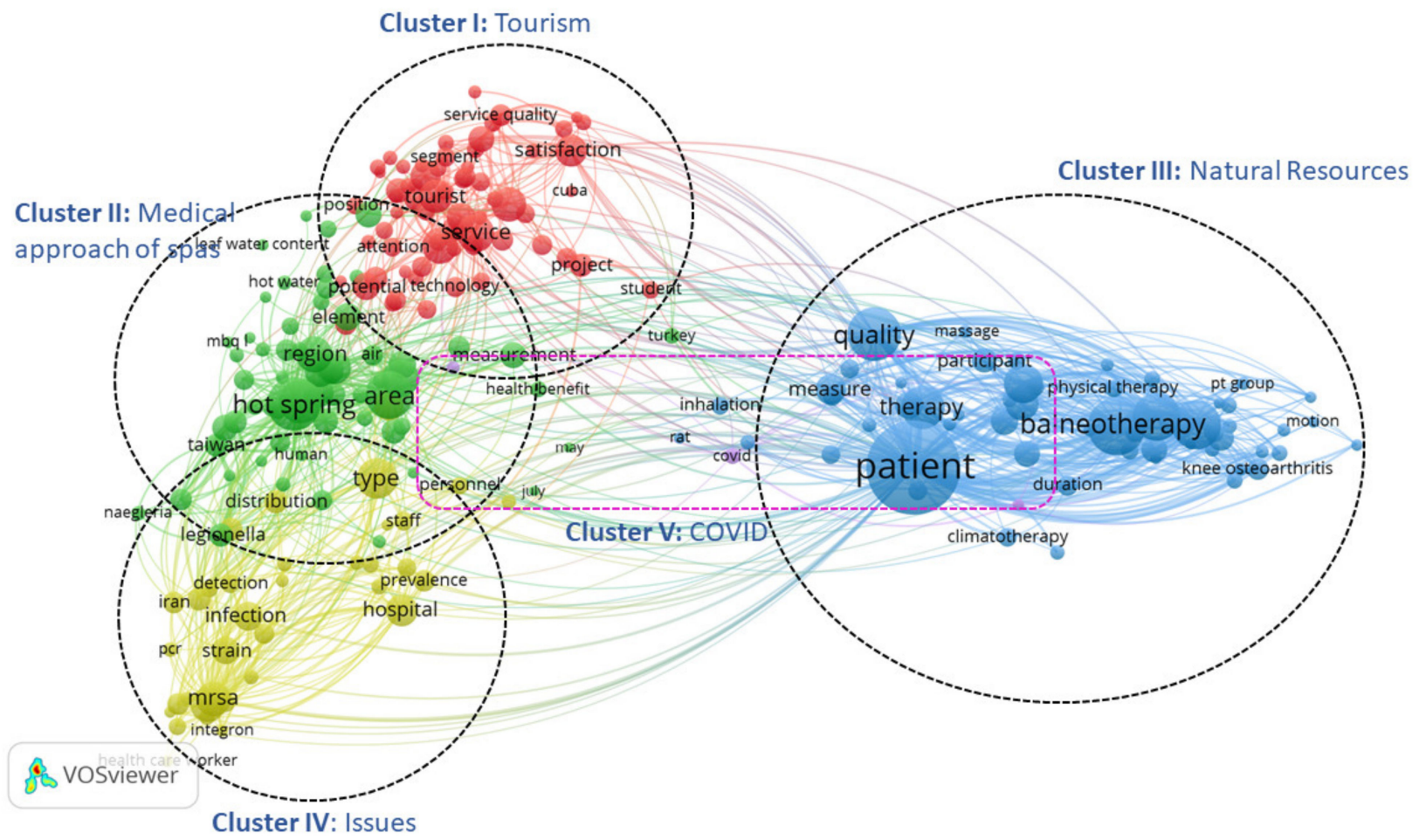

Figure 2. The structure of the clusters. Source: developed by the authors in VOS Viewer software 1.6.16.

The third cluster refers to the papers that contain title and abstract terms related to the natural resources of the spas. This includes as main keywords: patient (647), balneotherapy (243), quality (207), pain (181) and spa therapy (163). The terms from Cluster III can be divided into three main categories: diseases related to the spa field-patient (647), pain (181), improvement (111); natural resources_-bath (57), source (28), Dead Sea (15); and spa tourism niche/method-balneology (243), quality (207), spa therapy (163).

The fourth cluster includes articles focused on issues related to the spa industry and contains keywords like: type (124), mrsa (93), spa type (90), hospital (73), characteristic (62). The terms from cluster IV can be divided into four categories: destination-Iran (37), Australia (10); healthcare issues-hospital (73), prevalence (36), health care (21); issues related to spa activity-mrsa (93), infection (62), distribution (43); and spa industry (type (124), spa type (90), characteristic (62).

The fifth cluster related to the COVID-19 disease has repetitive keywords such as COVID (21), availability (13) and meta-analysis (11).

\subsection{Studies in Spa Field Connected to COVID-19 Research (IV)}

The analysis of researchers in linking the COVID-19 disease to the spa industry revealed two terms that directly connect the two directions: PCR, with an occurrence of 17 which is part of the Cluster IV; and COVID, with an occurrence of 21 which is part of the Cluster V (Figure 3).

The item COVID has in total 31 links, with a total link strength of 511. It is connected to patient, balneotherapy and exercise-terms from Cluster III, with availability and metaanalysis; items from Cluster V, with "service"; from Cluster IV, with prevalence and outbreak; and with Turkey and May items from Cluster II. The item PCR has in total 61 links with a total link strength of 354. It is connected with infection and mrsa from Cluster IV and with hot spring and acanthamoeba from Cluster II. 


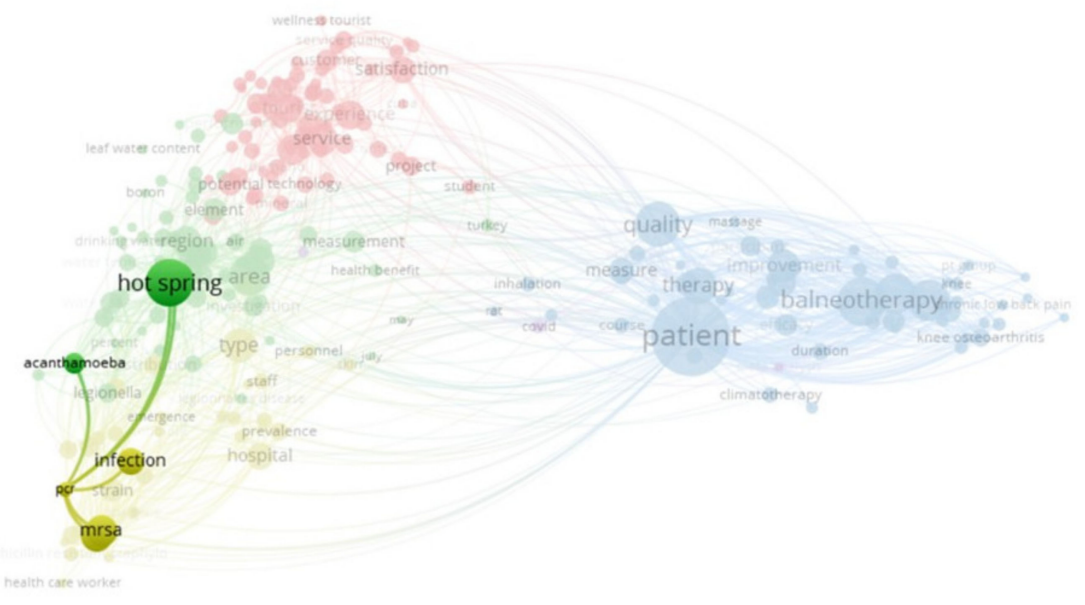

\& VOSviewer

(a)

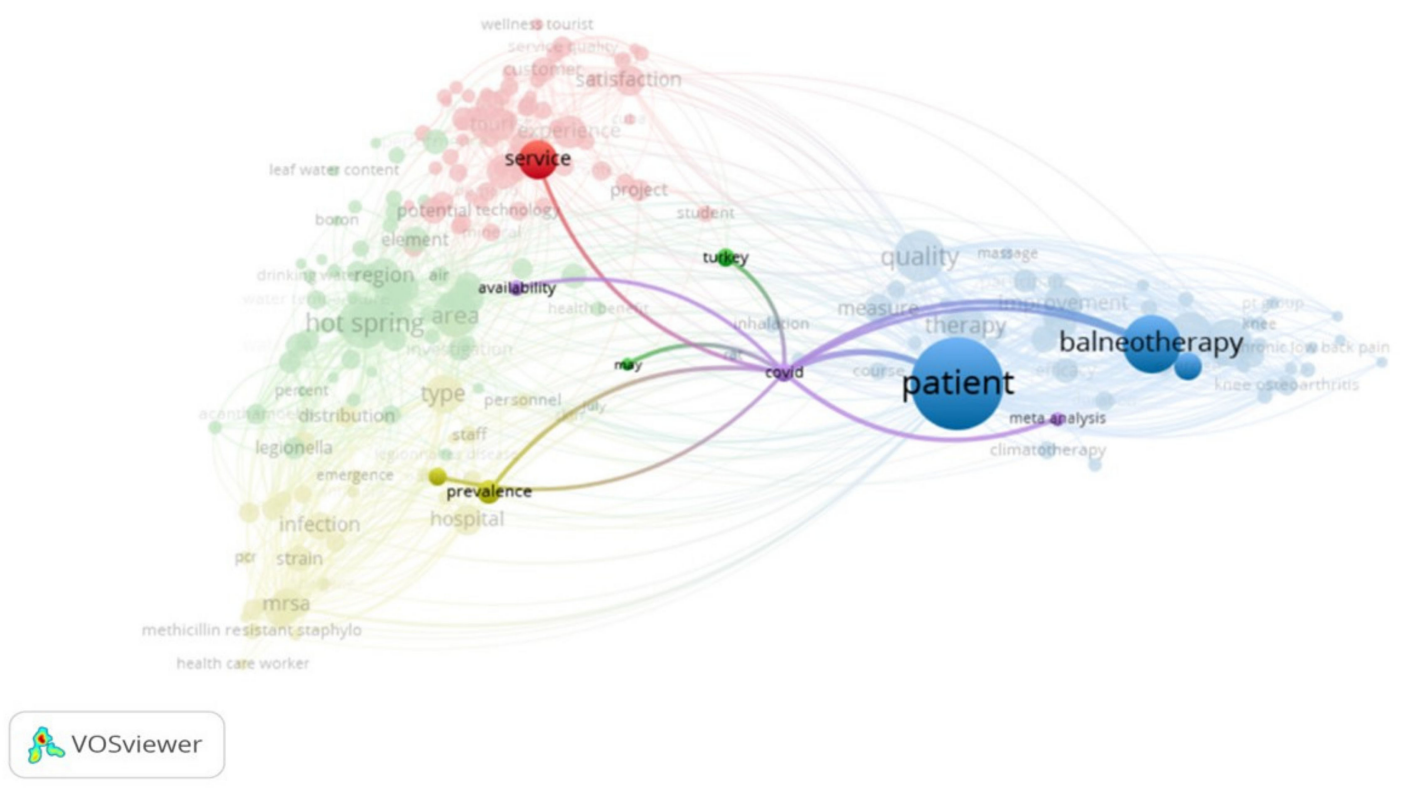

(b)

Figure 3. The structure of the clusters. Source: developed by the authors in VOS Viewer software 1.6.16. (a) Cluster IV-the link between the research interest in the spa field with the COVID-19 disease; (b) Cluster V-the link between the research interest in the spa field with the COVID-19 disease.

\section{Discussion}

Medical spa activity is recognised for its complimentary use in a wide variety of treatments, and many European countries accept its role in healthcare. The present investigation of research trends of medical spas using the co-word analyses presents an important insight into the main topics of interest for the academic environment. It explains the degree of maturity of the field in terms of research, focusing on the past and future research trends in the medical spa field from touristic and medical perspectives.

The main result of the research highlights the characteristics of knowledge production in the medical spa area and the future possible trends in this regard. The analysis revealed that academic researchers focused on subjects that illustrate four main aspects of medical spas: the research of touristic aspects, the medical side of the spas, the use of the natural 
resources and the main issues in the field. The picture is completed by a fifth subject that was treated by researchers in their studies: the link between the COVID-19 health crisis and the possibility to provide cost-effective post-recovery treatment for COVID-19 patients in medical spas.

The analysis of the research trends also shows the presence of a limited number of knowledge production poles represented by research teams, mainly from Europe and the USA, that prefer to disseminate their results in journals with high visibility from Europe and the USA.

The results of the present study illustrate the dynamics of the spa industry in the last years. Our investigation considered articles and proceedings included in WOS Core published between 1997 and 2021 (March) and shows that the highest interest in the academic environment related to spa research from the touristic and medical/health perspectives started in 2007.

The overall image of the papers and journals analysed in the spa industry (i) revealed that the ten most visible publications are from Europe (5 journals, with 44 articles in total) and the USA (5 journals, with 52 articles in total), being well ranked in WOS Core, with eight out of ten journals having an impact factor (Q1, Q2 or Q3) which gives the published papers high visibility. The country/region of origin of the ten journals is, in each case, a recognised spa destination, like the USA, Poland, Romania, Switzerland, Germany and The Netherlands. The study results also show the high number of papers related to the spa field from the touristic and medical/health perspective in 2020 and the first quarter of 2021 (almost 25\% of the total articles published in the first ten ranked journals).

The country/region of origin of the funding bodies that supported research in the spa field followed a different pattern than the ten publications origins (ii). The funding entities mainly originated from the USA, Asia (China, Japan, Taiwan), Middle East (Iran) and Europe (France, Poland and Italy). The interest to support research published in journals included in WOS Core collection started to be evident in 2015. Until that year, the number of total funded papers in the spa field (that met the present study's selection criteria) accounted for around $20 \%$ of the total of funded papers; after 2015, the number of financed papers increased dramatically, recording a peak in 2019 (18\% of the total funded papers were published in 2019).

The authors' focus in the published papers was in one of the following five categories (clusters): tourism issues (i), the medical approach to spas (ii), natural resources use (iii), healthcare (iv) and the relation of the spas to COVID-19 recovery therapies (v). The investigation of the repetitive terms present in the metadata of the papers (articles and proceedings) shows the research teams' interest in linking the spa activity to the medical approach of the industry. The terms with the highest occurrence: "patient" and "balneotherapy" are connected with most of the words from the other clusters. The structure of all the five clusters shows researchers' interest in investigating spas from a health perspective. The touristic approach of the published studies links touristic services and tourists' satisfaction to the quality of the therapies, natural resources and the diseases that can be treated in different destinations.

The results of the present study indicate a new cluster of interest in published papers since 2020 related to the COVID-19 disease (v). It shows that research teams started to connect spa therapies with the COVID-19 disease. The limited timespan (the COVID19 pandemic began in March 2020) and the appearance of this distinctive cluster in the present co-word analysis shows that researchers in the field identified the link between the therapies in medical spas and the new disease and focused their research on highlighting this link and the opportunity to increase awareness among the stakeholders about this option.

However, there are plenty of issues that providers should consider in this new context. Besides the safety aspect of travelling after the pandemic situation will not be a health threat anymore and the contraindications for specific categories of patients to follow a recovery treatment in a medical spa, tourists' behaviour should also be considered. The 
hospitality sector has already faced significant changes in the profile of tourists in the last years in terms of age [113], preferences and knowledge [114]. As a plus, after a year of social distancing and movement restrictions, the changes in tourist behaviour are expected to be more visible and complex. Therefore, the new way of doing tourism will imply less social contact and force the stakeholders to think about their market strategies and focus on their strengths more.

\section{Conclusions}

The spa industry reflects the evolution of tourists' preferences in time, and as a result, in the last decades, many niches that meet the actual tourists' needs have developed. The industry's main component, which also has the longest tradition, is the medical spa, which started to be preferred again by the tourists due to the present trend of having a healthy lifestyle. The recognition of medical spas by many European healthcare systems as being complementary to the classical medical treatment of many diseases helps the providers to attract a relative stable flow of tourists annually.

Medical spa activity has a long tradition, and its continuity dates for millennia. The archaeological evidence in European countries from all regions prove that people have known about the healing properties of natural factors and travelled to improve their health since antiquity. Despite the long tradition for "taking the waters" in Europe, the research in this area is still limited and mainly focused on the chemical composition of the natural factors. The touristic and medical/health perspectives are less investigated, and the knowledge production still has gaps. Moreover, the COVID-19 health crisis and the need to find cost-effective solutions for post-recovery treatment bring new research direction since medical spa resorts are suitable for treating respiratory diseases.

In this context, the current study approach helps the stakeholders in the field to identify the past trends in medical spa research, the key research teams, and journals that provide and disseminate knowledge. The article's results highlight another essential aspect of research: funding distribution, showing that the medical spa is now on an ascendant trend in funding interest. Another aspect that is shown is the new trend in medical spa research that links the COVID-19 post-recovery treatment to the medical spa expertise and activity.

Therefore, the present study's results show a switch in the research interest from studying classical issues of the spas, like the medical approach and the tourists' focus of the spas, to a new approach: the possibility of using spa therapies for COVID-19 recovery. The dynamic of the funding bodies' interest in the spa field indicates the spa industry is developing its visibility and generating more interest, mainly from the medical/health perspectives (Cluster II and Cluster III have the highest number of terms from the medical/health perspective). It also indicates that the spa field has not reached maturity in research, and there is still room for future investigations. Moreover, the attention switch to a new subject, like the one illustrated in Cluster V (keywords related to the COVID-19 disease), indicates that new niches might occur soon which will create a vast number of opportunities for all the stakeholders in the spa industry.

Considering the study results, we believe that spa tourism in general and medical spa tourism in particular have the opportunity to rebrand as a possible option for providing COVID-19 recovery treatment. However, in order to succeed in implementing a durable infrastructure for post-recovery treatment, medical spas should work closely with the healthcare systems of countries with a long tradition in using spa therapies as complementary therapies in treating various diseases, such as Romania, Poland, Check Republic, and find a suitable solution to help the public medical systems fight against the pandemic situation. The dynamics of the spa industry in terms of knowledge production (articles, proceedings) and the development of a new research trend (the connection between medical spas and post-COVID-19 recovery) prove that the spa field is still developing. In this context, new opportunities may occur, and all the stakeholders should be aware of the past and future trends in the industry. 
Knowing the industry features and anticipating future trends of interest are essential in any field. The present research represents helpful insights for the stakeholders, especially for the authorities from the countries with spa potential and helps them to identify the industry's actual and future potential trends. The results of the present co-word analysis indicate the appearance of new research interest in a short period after the COVID-19 pandemic started to affect every country/region. This shows that the connection between medical spas' activity and post-COVID-19 recovery might be a real trend in the near future, and the providers should be ready to adapt their offer to the new market's needs.

Considering that the present study identified this new tendency in research at a beginning stage, we aim to continue our research and monitor this new focus in research in the next years while expanding our analysis to other two databases: Scopus and PubMed. In this way, we intend to mitigate one of the limits of our study which is the restricted base for analysed papers (WOS database). Expanding our research base with articles and proceedings that are not included only in the WOS database would improve the possibility to anticipate other future trends in research. Another limitation of the current article is the lack of the stakeholders' opinion regarding the research in the medical spa field. We intend to focus our future study on the possible new trends in research from the point of view of the providers of medical spa services and of the local and national authorities directly interested in this field. In this way, we could complete the image of the medical spa research with the degree overlap between the academic approach and the stakeholders' needs.

Author Contributions: Conceptualisation, A.-C.A., P.N., D.A. and B.G.N.; methodology, A.-C.A., P.N. and D.A.; software, A.-C.A.; validation, P.N. and D.A.; resources, D.A.; data curation, A.-C.A., P.N. and D.A.; writing, A.-C.A., P.N., D.A. and B.G.N.; All authors have read and agreed to the published version of the manuscript.

Funding: This research received no external funding.

Data Availability Statement: Data is contained within the article.

Conflicts of Interest: The authors declare no conflict of interest.

\section{Appendix A}

Table A1. The structure of the five clusters included in the research.

\begin{tabular}{|c|c|c|}
\hline Cluster & Category of Terms & Terms (Occurrence) \\
\hline \multirow[b]{4}{*}{ Cluster I } & Destination & $\begin{array}{l}\text { destination (48); Poland (33); Romania (27); Thailand (17); Slovakia (15); Spain } \\
\text { (13); Cuba (11) }\end{array}$ \\
\hline & Tourist Experience & $\begin{array}{l}\text { experience (90); culture (34); relaxation (27); preference (25); food (23); pleasure } \\
\text { (15); recreation (12); reliability (12) }\end{array}$ \\
\hline & Future issues & $\begin{array}{l}\text { technology (30); growth (24); innovation (24); evolution (23); sustainable } \\
\text { development (15); future (13) }\end{array}$ \\
\hline & Tourism industry & $\begin{array}{l}\text { service (108); resource (95); tourist (82); satisfaction (78); spa tourism (66); } \\
\text { sector(62); potential (54); customer (50); visitor (43); medical spa (38); service } \\
\text { quality (36); hotel (35); context (33); concept (30); demand (30); knowledge (30); } \\
\text { mineral (29); opportunity (29); spa industry (29); wellness (29); segment (28); } \\
\text { spas (28); attention(26); way (24); client (22); loyalty (22); spa goer (22); spa } \\
\text { hotel (21); spa service (21); health tourism (20); nature (20); spa company (20); } \\
\text { tourism industry (20); natural resource (18); spa facility (17); creation (15); } \\
\text { business model (14); wellness tourism (14); wellness tourist (13); hot spring } \\
\text { resort (12) }\end{array}$ \\
\hline
\end{tabular}


Table A1. Cont.

\begin{tabular}{|c|c|c|}
\hline Cluster & Category of Terms & Terms (Occurrence) \\
\hline \multirow{4}{*}{ Cluster II } & Destination & $\begin{array}{l}\text { area (169); region (95); city (54); site (45); Taiwan (42); Turkey (21); resident (19); } \\
\text { Serbia (19); China (16); England (10) }\end{array}$ \\
\hline & Medical aspects & $\begin{array}{l}\text { measurement (52); performance (49); investigation (48); legionella (43); } \\
\text { acanthamoeba (34); occurrence (31); efficiency (24); health benefit (19); } \\
\text { naegleria (18); organism (17); human health (14); legionnaires disease (13); mbq } \\
1 \text { (12); human (11) }\end{array}$ \\
\hline & Risk & $\begin{array}{l}\text { radon (55); metal (22); health risk (19); radon concertation (16); heavy metal } \\
(11) \text {; radium (10) }\end{array}$ \\
\hline & SPA issues & $\begin{array}{l}\text { hot spring (208); temperature (102); source (81); spring (67); environment (66); } \\
\text { water sample (51); species (42); spring water (40); activity concentration (37); } \\
\text { child (31); water temperature (31); air (30); spa pool (25); groundwater (23); hot } \\
\text { spring tourism (23); soil (19); water quality (19); drinking water (16); hot spring } \\
\text { water (16); hot water (16); hot spring hotel (15); world health organization (12); } \\
\text { borom (10); leaf water content (10); July (9); May (8) }\end{array}$ \\
\hline \multirow{3}{*}{ Cluster III } & Diseases related & $\begin{array}{l}\text { patient (647); pain (181); improvement (111); function (82); measure (70); } \\
\text { effectiveness (54); osteoarthritis (51); efficacy (49); knee osteoarthritis (34); } \\
\text { significant improvement (31); duration (30); controlled trial (27); significant } \\
\text { difference (26); disability (23); beneficial effect (22); fibromyalgia (20); fatigue } \\
\text { (19); knee (19); psoriasis (18); pain intensity (15); chronic low back pain (14); } \\
\text { rheumatoid arthritis (14); anxiety (13); positive effect (13); chronic shoulder } \\
\text { pain (12); copd (11); significant decrease (11); elderly patient (10) }\end{array}$ \\
\hline & Resources & bath (57); course (28); Dead Sea (15); \\
\hline & Spa tourism niche/method & $\begin{array}{l}\text { balneotherapy (243); quality (207); spa therapy (163); therapy (137); exercise } \\
\text { (52); participant (45); physician (29); climatotherapy (27); physical therapy (23); } \\
\text { thermal therapy (23); inhalation (22); spa group (19); physical activity (18); } \\
\text { treatment group (18); medical treatment (16); exercise therapy (14); massage } \\
\text { (14); pt group (14); tap water (14); balneotherapy group (12); hydrotherapy } \\
\text { (12); movement (12); motion (11) }\end{array}$ \\
\hline \multirow[t]{4}{*}{ Cluster IV } & Destination & Iran (37); Australia (10) \\
\hline & Healthcare & $\begin{array}{l}\text { hospital (73); prevalence (36); health care (21); emergence (18); pcr (17); public } \\
\text { health (15); antibiotic (14); health care worker (10) }\end{array}$ \\
\hline & Spa issues & $\begin{array}{l}\text { mrsa (93); infection (62); distribution (43); bacterium (42); pathogen (40); } \\
\text { resistance (32); staphylococcys aureus (29); detection (27); methicillin resistant } \\
\text { staphylococcus aureus (23); mrsa strain (21); mlst (14); mssa (11) }\end{array}$ \\
\hline & Spa & $\begin{array}{l}\text { type (124); spa type (90); characteristic (62); strain (59); spa typing (36); staff } \\
\text { (26); personnel (24); skin (17); spa gene (17) }\end{array}$ \\
\hline Cluster V & COVID-19 & covid (21); availability (13); meta-analysis (11) \\
\hline
\end{tabular}

\section{References}

1. OECD. OECD Tourism Trends and Policies 2020; OECD: Paris, France, 2020.

2. UNWTO. World Tourism Barometer; UNWTO: Madrid, Spain, 2020; Volume 18, p. 5.

3. Spinthiropoulos, K.; Nikas, C.; Zafeiriou, E. Sector Analysis and Economic Growth in Greece: The Domination of Tourism over Other Sectors. In Economic Growth in the European Union; Nikas, C., Ed.; Springer: Cham, Switzerland, 2020; pp. 167-176.

4. Della Lucia, M.; Segre, G. Intersectoral local development in Italy: The cultural, creative and tourism industries. Int. J. Cult. Tour. Hosp. Res. 2017, 11, 3. [CrossRef]

5. Balsalobre-Lorente, D.; Oana Madalina, D.; Festus Victor, B.; Festus Fatai, A. The asymmetric impact of air transport on economic growth in Spain: Fresh evidence from the tourism-led growth hypothesis. Curr. Issues Tour. 2019, 24, 503-519. [CrossRef]

6. Giovanni, B. Estimating the tourism induced environmental Kuznets curve in France. J. Sustain. Tour. 2018, 26, 12. [CrossRef]

7. Nistoreanu, P.; Pădueran, A.; Nica, A.; Tănase, M. Aspects of Tourism Comsumption Behavior. New Trends Sustain. Bus. Consum. 2018, 4, 669-675.

8. Palacios, H.; de Almeida, M.H.; Sousa, M.J. A bibliometric analysis of trust in the field of hospitality and tourism. Int. J. Hosp. Manag. 2021, 95, 102944. [CrossRef] 
9. Mertzanis, C.; Papastathopoulos, A. Epidemiological susceptibility risk and tourist flows around the world. Ann. Tour. Res. 2021, 86, 103095. [CrossRef]

10. Osti, L.; Nava, C.R. Loyal: To What Extent? A shift in destination preference due to the COVID-19 pandemic. Ann. Tour. Res. Empir. Insights 2020, 1, 100004. [CrossRef]

11. Zheng, D.; Luo, Q.; Ritchie, B.W. Afraid to travel after COVID-19? Self-protection, coping and resilience against pandemic 'travel fear'. Tour. Manag. 2021, 83, 104261. [CrossRef]

12. Pappas, N.; Glyptou, K. Accommodation decision-making during the COVID-19 pandemic: Complexity insights from Greece. Int. J. Hosp. Manag. 2021, 93, 102767. [CrossRef]

13. Khaltaev, N.; Solimene, U.; Vitale, F.; Zanasi, A. Balneotherapy and hydrotherapy in chronic respiratory disease. J. Thorac. Dis. 2020, 12, 4459-4468. [CrossRef]

14. Navarrete, A.P.; Shaw, G. Spa tourism opportunities as strategic sector in aiding recovery from Covid-19: The Spanish model. Tour. Hosp. Res. 2020, 21, 245-250. [CrossRef]

15. T. E. S. Association. Corona Recovery Concept in the European Medical Spas and Climate Health Resorts. 2021. Available online: https: / / www.europeanspas.eu/en/corona-recovery-concept (accessed on 20 January 2021).

16. Masiero, S.; Maccarone, M.C.; Agostini, F. Health resort medicine can be a suitable setting to recover disabilities in patients tested negative for COVID-19 discharged from hospital? A challenge for the future. Int. J. Biometeorol. 2020, 61, 1807-1809. [CrossRef]

17. Ridderstaat, J.; Singh, D.; DeMicco, F. The impact of major tourist markets on health tourism spending in the United States. J. Destin. Mark. Manag. 2019, 11, 270-280. [CrossRef]

18. Mainil, T.; Eijgelaar, E.; Klijs, J.; Nawijn, J.; Peeters, P. Research for TRAN Committee—Health Tourism in the EU: A General Investigation; European Parliament, Policy Department: Brussels, Belgium, 2017.

19. Avram, A.C. The Impact of Rural Tourism on Wellbeing: Romania's Case. In New Trends and Opportunities for Central and Eastern European Tourism; Nistoreanu, P., Ed.; IGI Global: Hershey, PA, USA, 2020; pp. 281-298. [CrossRef]

20. Connell, J. Medical Tourism; Cabi: London, UK, 2011.

21. European Commission. Conceptual Framework on Health and Tourism-An Interregional Point of View; European Commission: Brussels, Belgium, 2018.

22. Franzblau, L.E.; Chung, K.C. Impact of Medical Tourism on Cosmetic Surgery in the United States. Plast. Reconstr. Surg. 2013, 1. [CrossRef]

23. Ying, T.; Wen, J.; Tan, X. Does traditional Chinese medicine attract inbound tourists to China? An investigation from Russian tourists' perspectives. Anatolia 2021, 31, 662-665. [CrossRef]

24. Pesonen, J.A. Information and communications technology and market segmentation in tourism: A review. Tour. Rev. 2013, 14-30. [CrossRef]

25. Castaneda, J.A.; Frias, D.M.; Rodriguez, M.A. The influence of the Internet on destination satisfaction. Internet Res. 2007, 402-420. [CrossRef]

26. Soegoto, E.S.; Purnama, F.A.; Hidayat, A. Role of Internet and Social Media for Promotion Tools. In IOP Conference Series. Materials Science and Engineering; IOP Publishing: Bristol, UK, 2018; Volume 407. [CrossRef]

27. Goyal, N.; Sharma, S.K. Use of government tourism websites as a tool for promoting tourism. Int. J. Hosp. Tour. Syst. 2013, 6, 44-51.

28. Alberti, F.G.; Giusti, J.D.; Papa, F.; Pizzurno, E. Competitiveness policies for medical tourism clusters: Government initiatives in Thailand. Int. J. Econ. Policy Emerg. Econ. 2014, 7, 3. [CrossRef]

29. Kelley, E. Medical Tourism; World Health Organization: Geneva, Switzerland, 2013.

30. Davison, S.P.; Hayes, K.D.; LaBove, G.; Shaffer, P. The Price of Medical Tourism: The Legal Implications of Surgery Abroad. Plast. Reconstr. Surg. 2018, 142, 1075-2018. [CrossRef] [PubMed]

31. Danovitch, G.M.; Al-Mousawi, M. The Declaration of Istanbul-Early impact and future potential. Nat. Rev. Nephrol. 2012, 8, 6. [CrossRef]

32. Hall, C.M. Health and medical tourism: A kill or cure for global public health? Tour. Rev. 2011, 4-15. [CrossRef]

33. Wahed, H. Ethical and Legal Issues in Medical Tourism. IIUM Law J. 2015, 23, 227-245. [CrossRef]

34. Crooks, V.A.; Turner, L.; Cohen, I.G.; Bristeir, J.; Snyder, J.; Casey, V.; Whitmore, R. Ethical and legal implications of the risks of medical tourism for patients: A qualitative study of canadian health and safety representatives' perspectives. BMJ Open 2013, 3, e002302. [CrossRef] [PubMed]

35. BMI. Hungary Tourism Report; Fitch Solutions Group Limited: London, UK, 2017.

36. Kovacs, E.; Szocska, G. Vacation for your teeth'-Dental tourists in Hungary from the perspective of Hungarian dentists. Br. Dent. J. 2013, 215, 415-418. [CrossRef] [PubMed]

37. Österle, A.; Balázs, P.; Delgado, J. Travelling for teeth: Characteristics and perspectives of dental care tourism in Hungary. $\mathrm{Br}$. Dent. J. 2009, 206, 425-428. [CrossRef] [PubMed]

38. Lubowiecki-Vikuk, A.; Kurkowiak, J. Medical Tourism Potential of Central and Eastern Europe: Attempt at Classification. CBU Int. Conf. Proc. 2017, 5. [CrossRef]

39. BMI. Bulgaria Tourism Report; Fitch Solutions Group Limited: London, UK, 2018. 
40. Ractham, P.; Chen, C.; Nakayama, M. The Trust in Online Discussion Forums and How they Influence Patients' Intention to Adopt Medical Tourism Services. In Proceedings of the 2013 International Conference on e-Business (ICE-B), Reykjavik, Iceland, 29-31 July 2013.

41. Ríordáin, R.N.; McCreary, C. Dental patients' use of the Internet. Br. Dent. J. 2009, 217, 583-586. [CrossRef] [PubMed]

42. Voigt, C.; Brown, G.; Howat, G. Wellness tourists: In search of transformation. Tour. Rev. 2011, 16-30. [CrossRef]

43. Chen, K.H.; Chang, F.-H.; Wu, C. Investigating the wellness tourism factors in hot spring hotel customer service. Int. J. Contemp. Hosp. Manag. 2013, 1092-1114. [CrossRef]

44. Dillette, A.K.; Douglas, A.C.; Andrzejewski, C. Dimensions of holistic wellness as a result of international wellness tourism experiences. Curr. Issues Tour. 2020, 24, 794-810. [CrossRef]

45. Xie, L.; Guan, X.; He, Y.; Huan, T.-C. Wellness tourism: Customer-perceived value on customer engagement. Tour. Rev. 2021. [CrossRef]

46. Huang, L.; Xu, H. Therapeutic landscapes and longevity: Wellness tourism in Bama. Soc. Sci. Med. 2018, 24-32. [CrossRef] [PubMed]

47. Csirmaz, E.; Peto, K. International trends in recreational and wellness tourism. Procedia Econ. Financ. 2015, 32, 755-762. [CrossRef]

48. Vildova, E.; Martincik, D.; Tluchor, J.; Jakubikova, D. Measuring Customer Satisfaction and Loyalty in Spa Companies. E M Ekon. Manag. 2015, 18, 151-168. [CrossRef]

49. Smith, M.; Puczko, L. Health \& Wellness Tourism a Focus on The Global Spa Experience; Routledge: London, UK, 2014.

50. Connell, J. The Antiquity of Health Tourism. In Medical Tourism; CABI: Sydney, Australia, 2011; pp. 12-22.

51. Tresidder, R. Health and Medical Tourism. In Research Themes for Tourism; CABI: Wolverhampton, UK, 2011 ; pp. $266-275$.

52. Travis, A. Resorts Are Not Forever. In Planning for Tourism, Leisure and Sustainability: International Case Studies; CABI: Birmingham, UK, 2011; pp. 279-286.

53. Pérez, C.P.G.; Soutelo, S.G.; Mosqueira, M.L.M.; Soto, J.L.L. Spa techniques and technologies: From the past to the present. Sustain. Water Resour. Manag. 2019, 5, 71-81. [CrossRef]

54. Bruce, K.; Jason, M. Incorporating a Medical Spa into a Physician-Run Practice. Dermatol. Clin. 2008, 26, 307-319. [CrossRef]

55. Fioravantia, A.; Karagülle, M.; Bender, T.; Karagülle, M.Z. Balneotherapy in osteoarthritis: Facts, fiction and gaps in knowledge. Eur. J. Integr. Med. 2017, 9, 148-150. [CrossRef]

56. Varga, C. To treat or not to treat? Misbeliefs in spa water disinfection. Int. J. Biometeorol. 2019, 63, 1135-1138. [CrossRef]

57. Kamioka, H.; Mori, Y.; Nagata, K.; Iwanaga, S.; Uzura, M.; Yamaguchi, S. Relationship of daily hot water bathing at home and hot water spa bathing with underlying diseases in middle-aged and elderly ambulatory patients: A Japanese multicenter cross-sectional study. Complementary Ther. Med. 2019, 43, 232-239. [CrossRef]

58. Irène, B.; Sandrine, M.; Christophe, L.; Patrick, M.; Patrick, D. Sensory analysis of four medical spa spring waters containing various mineral concentrations. Int. J. Dermatol. 2001, 38, 784-786. [CrossRef]

59. Mihăilă, D.; Bistricean, P.-I.; Briciu, A.-E. Assessment of the climate potential for tourism. Case study: The North-East Development Region of Romania. Theor. Appl. Climatol. 2019, 137, 601-622. [CrossRef]

60. Surdu, O.; Tuta, L.-A.; Surdu, T.V.; Surdu, M.; Mihailov, C.I. Sustainable Development of Balneotherapy/Thermalisme in Romania. J. Environ. Prot. Ecol. 2015, 16, 1440-1446.

61. Nasermoaddeli, A.; Kagamimori, S. Balneotherapy in Medicine: A Review. Environ. Health Prev. Med. 2005, 10, 171-179. [CrossRef] [PubMed]

62. Kevan, S.M. Quests for cures: A history of tourism for climate and health. Int. J. Biometeorol. 1993, 37, 113-124. [CrossRef] [PubMed]

63. Gutenbrunner, C.; Bender, T.; Karagülle, Z. A proposal for a worldwide definition of health resort medicine, balneology, medical hydrology and climatology. Int. J. Biometeorol. 2010, 54, 495-507. [CrossRef]

64. TomićK, N.; Košić, K. Developing the Spa Assessment Model (SAM) and its application on the Kopaonik-Jastrebac spa zone (Serbia). Tour. Manag. Perspect. 2020, 36, 100753. [CrossRef]

65. Lotti, T.; Freedman, D. Balneology and spa treatments in dermatology: The european point of view. J. Eur. Acad. Dermatol. Venereol. 1994, 3, 449-450. [CrossRef]

66. Parish, L.C.; Witkowski, J.A. Dermatologic balneology: The American view of waters, spas, and hot springs. J. Eur. Acad. Dermatol. Venereol. 1994, 3, 465-467. [CrossRef]

67. Patterson, I. Different Travel Markets: Health and Wellness Tourism and Older Travellers. In Tourism and Leisure Behaviour in an Ageing World; Patterson, I., Ed.; CABI: St Lucia, Australia, 2018; pp. 203-215.

68. Thorsteinsdottir, K. The state of the European hotel spa sector. J. Retail. Leis. Prop. 2005, 4, 272-277. [CrossRef]

69. Dryglas, D.; Salamaga, M. Segmentation by push motives in health tourism destinations: A case study of Polish spa resorts. J. Destin. Mark. Manag. 2018, 9, 234-246. [CrossRef]

70. Kim, C.-G.; Lee, D.-G.; Oh, J.; Lee, Y.-H.; Lee, Y.J.; Song, P.H.; Song, C.-H.; Ku, S.-K. Effects of Balneotherapy in Jeju MagmaSeawater on Knee Osteoarthritis Model. Sci. Rep. 2020, 10, 1-14. [CrossRef]

71. Matsumoto, S. Evaluation of the Role of Balneotherapy in Rehabilitation Medicine. J. Nippon. Med. Sch. 2018, 85, 196-203. [CrossRef]

72. Gajdoš, O.; Kamenský, V.; Doskočilová, K.; Caithamlová, M.; Kubátová, I. Cost-utility analysis of cardiovascular outpatient rehabilitation care and spa treatment care for patients with heart disease. Cost Eff. Resour. Alloc. 2020, 18, 1-10. [CrossRef] 
73. Silva, A.; Oliveira, A.S.; Vaz, C.V.; Correia, S.; Ferreira, R.; Breitenfeld, L.; Martinez-de-Oliveira, J.; Palmeira-de-Oliveira, R.; Pereira, C.M.F.; Palmeira-de-Oliveira, A.; et al. Anti-inflammatory potential of Portuguese thermal waters. Sci. Rep. 2020, 10, 1-13. [CrossRef]

74. Masiero, S.; Maccarone, M.C.; Magro, G. Balneotherapy and human immune function in the era of COVID-19. Int. J. Biometeorol. Vol. 2020, 1433-1434. [CrossRef]

75. Antonelli, M.; Donelli, D. Respiratory rehabilitation for post-COVID19 patients in spa centers: First steps from theory to practice. Int. J. Biometeorol. 2020, 64, 1811-1813. [CrossRef]

76. Sinan, K. Spa therapy (balneotherapy) for rehabilitation of survivors of COVID-19 with persistent symptoms. Med. Hypotheses 2021, 146, 110472. [CrossRef]

77. Molinillo, S.; Ekinci, Y.; Whyatt, G.; Occhiocupo, N.; Stone, M. Private Label Management: Insights and Research Directions. In Handbook of Research on Strategic Retailing of Private Label Products in a Recovering Economy; IGI Global: Hershey, PA, USA, 2016.

78. Mulet-Forteza, C.; Genovart-Balaguer, J.; Mauleon-Mendeza, E.; Merigó, J.M. A bibliometric research in the tourism, leisure and hospitality fields. J. Bus. Res. 2019, 101, 819-827. [CrossRef]

79. Agapito, D. The senses in tourism design: A bibliometric review. Ann. Tour. Res. 2020, 83. [CrossRef]

80. Dragoş, C.M.; Dinu, V.; Pop, C.-M.; Dabija, D.-C. Scientometric approach of productivity in scholarly economics and business. Econ. Res. Ekon. Istraživanja 2014, 496-507. [CrossRef]

81. Kulakli, A. Integration of Data Mining and Business Intelligence in Big Data Analytics: A Research Agenda on Scholarly Publications. In Integration Challenges for Analytics, Business Intelligence, and Data Mining; IGI Global: Hershey, PA, USA, 2021.

82. Okumus, B.; Koseoglu, M.A.; Ma, F. Food and gastronomy research in tourism and hospitality: A bibliometric analysis. Int. J. Hosp. Manag. 2018, 73, 64-74. [CrossRef]

83. Koseoglu, M.A.; Rahimi, R.; Okumus, F.; Liu, J. Bibliometric studies in tourism. Ann. Tour. Res. 2016, 61, 180-198. [CrossRef]

84. Yang, K.C.C.; Kang, Y. Political Mobilization Strategies in Taiwan's Sunflower Student Movement on March 18, 2014: A TextMining Analysis of Cross-National Media Corpus. In Using New Media for Citizen Engagement and Participation; IGI Global: Hershey, PA, USA, 2020.

85. Sigala, M.; Kumar, S.; Donthu, N.; Sureka, R.; Joshi, Y. A bibliometric overview of the Journal of Hospitality and Tourism Management: Research contributions and influence. J. Hosp. Tour. Manag. 2021, 47, 273-288. [CrossRef]

86. Niñerola, A.; Sánchez Rebull, V.; Hernández-Lara, A.-B. Tourism Research on Sustainability: A Bibliometric Analysis. Sustainability 2019, 11, 1377. [CrossRef]

87. Vieira, E.S.; Madaleno, M.; Azevedo, G. Research on Corporate Governance: Bibliometric Analysis. In Comparative Research on Earnings Management, Corporate Governance, and Economic Value; IGI Global: Hershey, PA, USA, 2021.

88. Chen, C.; Song, M. Visualizing a field of research: A methodology of systematic scientometric reviews. PLoS ONE 2019, 14, e0223994. [CrossRef] [PubMed]

89. Sedighi, M. Application of word co-occurrence analysis method in mapping of the scientific fields (case study: The field of Informetrics). Libr. Rev. 2016, 52-64. [CrossRef]

90. Donthu, N.; Kumar, S.; Mukherjee, D.; Pandey, N.; Lim, W.M. How to conduct a bibliometric analysis: An overview and guidelines. J. Bus. Res. 2021, 285-296. [CrossRef]

91. He, Q. Knowledge discovery through co-word analysis. Libr. Trends 1999, 48, 133-159.

92. Virani, A.; Wellstead, A.M.; Howlett, M. Where is the policy? A bibliometric analysis of the state of policy research on medical tourism. Glob. Health Res. Policy 2020, 5, 19. [CrossRef]

93. de la Hoz-Correa, A.; Muñoz-Leiva, F.; Bakucz, M. Past themes and future trends in medical tourism research: A co-word analysis. Tour. Manag. 2018, 65, 200-211. [CrossRef]

94. Wahyudi, V.; Ilyas, J. Impact of Medical Tourism: A Systematic Review. In Proceedings of the 6th International Conference on Public Health 2019, Solo, Indonesia, 23-24 October 2019.

95. Rama, D.R.; Maldonado-Erazo, C.P.; Álvarez García, J. State of the Art of Research in the Sector of Thermalism, Thalassotherapy and Spa: A Bibliometric Analysis. Eur. J. Tour. Res. 2018, 19, 56-70.

96. Virani, A.; Wellstead, A.M.; Howlett, M. The north-south policy divide in transnational healthcare: A comparative review of policy research on medical tourism in source and destination countries. Glob. Health 2020, 16, 37. [CrossRef]

97. Pessot, E.; Spoladore, D.; Zangiacomi, A.; Sacco, M. Natural Resources in Health Tourism: A Systematic Literature Review. Sustainability 2021, 13, 2661. [CrossRef]

98. Escher, I. Sustainable development in sport as a research field: A bibliometric analysis. J. Phys. Educ. Sport 2020, 20 (Suppl. 5), 2803-2812. [CrossRef]

99. Durán Sánchez, A.; de la Cruz Del Río Rama, A.; Álvarez García, J. Bibliometric analysis of publications on wine tourism in the databases Scopus and WoS. Eur. Res. Manag. Bus. Econ. 2017, 23, 8-15. [CrossRef]

100. Centre for Science and Technology Studies. "VOSviewer". 2021. Available online: https:/ / www.vosviewer.com/ (accessed on 5 March 2021).

101. Boyack, K.W. Thesaurus-based methods for mapping contents of publication sets. Scientometrics 2017, 111, 1141-1155. [CrossRef]

102. Steven, O. ResearchGate and Academia.edu: Academic Social Networks. Behav. Soc. Sci. Libr. 2014, 33, 165-169. [CrossRef]

103. Deng, W. Using a revised importance-performance analysis approach: The case of Taiwanese hot springs tourism. Tour. Manag. 2007, 28, 1274-1284. [CrossRef] 
104. Corazzari, I.; Nisticò, R.; Turci, F.; Faga, M.G.; Franzoso, F.; Tabasso, S.; Magnacca, G. Advanced physico-chemical characterisation of chitosan by means of TGA coupled online with FTIR and GCMS: Thermal degradation and water adsorption capacity. Polym. Degrad. Stab. 2015, 112, 1-9. [CrossRef]

105. Bender, T.; Karagülle, Z.; Bálint, G.P.; Gutenbrunner, C.; Bálint, P.V.; Sukenik, S. Hydrotherapy, balneotherapy, and spa treatment in pain management. Rheumatol. Int. 2005, 25, 220-224. [CrossRef]

106. Coutts, A.M.; Tapper, N.J.; Beringer, J.; Loughnan, M.; Demuzere, M. Watering our cities: The capacity for Water Sensitive Urban Design to support urban cooling and improve human thermal comfort in the Australian context. Phys. Geogr. Earth Environ. 2013, 37, 2-28. [CrossRef]

107. Malachowa, N.; Sabat, A.; Gniadkowski, M.; Krzyszton-Russjan, J.; Empel, J.; Miedzobrodzki, J.; Kosowska-Shick, K.; Appelbaum, P.C.; Hryniewicz, W. Comparison of multiple-locus variable-number tandem-repeat analysis with pulsed-field gel electrophoresis, spa typing, and multilocus sequence typing for clonal characterisation of Staphylococcus aureus isolates. J. Clin. Microbiol. 2005, 43, 3095-3100. [CrossRef] [PubMed]

108. Forestier, R.; Desfour, H.; Tessier, J.-M.; Françon, A.; Foote, A.M.; Genty, C.; Rolland, C.; Roques, C.-F.; Bosson, J.-L. Spa therapy in the treatment of knee osteoarthritis: A large randomised multicentre trial. Ann. Rheum. Dis. 2010, 69, 660-665. [CrossRef] [PubMed]

109. Mak, A.H.N.; Wong, K.K.F.; Chang, R.C.Y. Health or Self-indulgence? The Motivations and Characteristics of Spa-goers. Int. J. Tour. Res. 2009, 11, 185-199. [CrossRef]

110. Franke, A.; Reiner, L.; Pratzel, H.G.; Franke, T.; Resch, K.L. Long-term efficacy of radon spa therapy in rheumatoid arthritis-a randomised, sham-controlled study and follow-up. Rheumatology 2000, 39, 894-902. [CrossRef]

111. Spinks, A.T.; Dunstan, R.H.; Harrison, T.; Coombes, P.; Kuczera, G. Thermal inactivation of water-borne pathogenic and indicator bacteria at sub-boiling temperatures. Water Res. 2006, 40, 1326-1332. [CrossRef]

112. Van Tubergen, A.; Boonen, A.; Landewé, R.; Rutten-Van Mölken, M.; Van der Heijde, D.; Hidding, A.; Van der Linden, S. Cost effectiveness of combined spa-exercise therapy in ankylosing spondylitis: A randomised controlled trial. Arthritis Rheum. 2002, 47, 459-467. [CrossRef]

113. Juul, M. Tourism and the European Union. Recent trends and policy developments. EPRS Eur. Parliam. Res. Serv. Depth Anal. Rep. 2015, 1-25. [CrossRef]

114. Gossling, S.; Scott, D.; Hall, C.M.; Ceron, J.-P.; Dubois, G. Consumer Behaviour and Demand Response of Tourists to Climate Change. Ann. Tour. Res. 2012, 39, 36-58. [CrossRef] 